\title{
IMPROVING THE UNDERSTANDING OF CONCEPTS OF MOMENTUM AND IMPULS OF STUDENTS BY IMPLEMENTATION OF EVIDENCE BASED LEARNING MODELS IN CLASS X SENIOR HIGH SCHOOL
}

\author{
Ullya Muflihatin*1), Nur Islami ${ }^{2)}$, Fakhruddin $Z^{3 \text { ). }}$. \\ ${ }^{1,2,3)}$ Physics Education, University of Riau \\ e-mail: ulya9672@gmail.com \\ nurislami@lecturer.unri.ac.id \\ faruqfisika@yahoo.com
}

\begin{abstract}
This research aims to describe and find out the increase in students' understanding of concepts in the indicators of translation, interpretation, and extrapolation in class X SMA 9 Pekanbaru by applying evidence based learning (EBL) learning models to the momentum and impulse material. This type of research is a quasi experimental. The research population was students of class X SMA 9 Pekanbaru in the Academic Year 2018/2019. The research sample consisted of 2 classes totaling 72 students, of which the experimental class $X I P A_{3}$ and the control class X IPA. Research data based on posttest scores understanding the concept of momentum and impulse material, obtained after the implementation of the learning model is given. Data were analyzed descriptively and inferentially to see an increase in students' understanding of concepts. The results of data analysis obtained an increase in students' understanding of the concept of class X IPA3 reaching $71.73 \%$ with the category of understanding the average concept is good, while the results of inferential analysis, there is a significant increase in understanding of the concept of momentum and impulse material. Thus, the application of evidence based learning models is effective in increasing students' understanding of concepts in the material momentum and impulses in class $X_{3}$ SMA 9 Pekanbaru.
\end{abstract}

Keywords: evidence based learning, momentum and impulse, understanding of concepts. 


\title{
PENINGKATAN PEMAHAMAN KONSEP MOMENTUM DAN IMPULS PESERTA DIDIK DENGAN PENERAPAN MODEL PEMBELAJARAN EVIDENCE BASED LEARNING DI KELAS X SMA
}

\author{
Ullya Muflihatin ${ }^{* 1)}$, Nur Islami ${ }^{2)}$, Fakhruddin $Z^{3)}$ \\ ${ }^{1,2,3)}$ Pendidikan Fisika, Universitas Riau
}

\begin{abstract}
Abstrak
Penelitian ini bertujuan untuk mendeskripsikan serta mengetahui peningkatan pemahaman konsep peserta didik pada indikator translation, interpretation, dan extrapolation di kelas X SMA 9 Pekanbaru dengan penerapan model pembelajaran evidence based learning (EBL) pada materi momentum dan impuls. Jenis penelitian yang digunakan adalah kuasi experimental. Populasi penelitian yaitu peserta didik kelas X SMA i 9 Pekanbaru Tahun Ajaran 2018/2019. Sampel penelitian terdiri dari 2 kelas yang berjumlah 72 orang peserta didik, yang mana kelas eksperimen X IPA 3 dan kelas kontrol X IPA $\mathrm{I}_{6}$. Data penelitian berdasarkan skor posttest pemahaman konsep materi momentum dan impuls, yang diperoleh setelah penerapan model pembelajaran diberikan. Data dianalisis secara deskriptif dan inferemsial untuk melihat peningkatan pemahaman konsep peserta didik. Hasil analisis data diperoleh peningkatan pemahaman konsep peserta didik kelas $\mathrm{X} \mathrm{IPA}_{3}$ mencapai $71,73 \%$ dengan kategori pemahaman konsep rata-rata adalah baik, sedangkan hasil analisis inferensial, terdapat peningkatan pemahaman konsep materi momentum dan impuls yang signifikan. Dengan demikian penerapan model pembelajaran evidence based learning efektif dalam meningkatkan pemahaman konsep peserta didik pada materi momentum dan impuls di kelas $\mathrm{X}_{3}$ SMA 9 Pekanbaru.
\end{abstract}

Kata kunci: evidence based learning, momentum dan impuls, pemahaman konsep.

\section{Pendahuluan}

Pendidikan merupakan keperluan mutlak yang harus dipenuhi dalam kehidupan bermasyarakat melalui seluruh proses pembelajaran (Hasan, 2014). Salah satu bidang pelajaran sains adalah pelajaran fisika. Pembelajaran fisika harus mengarah kepada pembelajaran yang bersifat transaksional, yaitu pembelajaran yang melibatkan guru dan peserta didik secara aktif, sehingga pembelajaran tidak hanya berasal dari guru tetapi juga berasal dari peserta didik (Azizah, et. al., 2014).

Menurut Azizah, et. Al. (2014), fisika merupakan bagian dari sains yang berkaitan dengan cara mencari tahu tentang fenomena alam secara sistematis sehingga proses pembelajarannya bukan hanya sekedar penguasaan kumpulan pengetahuan berupa fakta-fakta, konsep-konsep atau prinsip-prinsip saja, tetapi juga merupakan suatu proses penemuan. Pendidikan fisika diarahkan untuk mencari tahu daan berbuat sehingga dapat membantu peserta didik untuk memperoleh pemahaman yang lebih mendalam tentang alam sekitar serta sebagai pengembangan kemampuan peserta didik dalam bidang sains (Dwiyanto, 2005).

Young \& Roger (2002) mengatakan fisika adalah ilmu pengetahuan yang bersifat eksperimental. Fisikawan mengamati fenomena alam dan berusaha menemukan pola dan prinsip yang menghubungkan fenomenafenomena ini, pola ini disebut hukum atau prinsip fisika. Fisika bukanlah sekedar kumpulan fakta dan prinsip. Fisika adalah proses yang membawa pada prinsip-prinsip umum yang mendeskripsikan bagaimana perilaku dunia fisik. Fisika sebagai ilmu pengetahuan yang paling mendasar, karena berhubungan dengan perilaku dan struktur benda (Giancoli, 2001).

Selama ini proses pembelajaran fisika cenderung bersifat teacher centered dengan metode pembelajaran yang cenderung monoton dan kurang melibatkan peserta didik dalam menemukan suatu konsep pada proses pembelajaran. Pembelajaran seperti itu menimbulkan ketidaktahuan pada diri peserta didik mengenai proses, maupun sikap ilmiah terhadap konsep fisika yang diperoleh. Oeh 
karena itu, hendaknya dilakukan perubahan paradigma proses pembelajaran. Perubahan paradigma yang dimaksud adalah perubahan dari pembelajaran yang bersifat teacher centered ke pembelajaran yang berorientasi pada student centered (Erlina Sofiani, 2011). Hal ini menekankan peserta didik untuk terlibat aktif dalam proses pembelajaran sebagaimana peserta didik yang aktif dalam pembelajaran berbeda pemahamannya dengan peserta didik kurang aktif.

Salah satu cara dalam memahamkan konsep pada peserta didik adalah dengan menerapkan suatu model pembelajaran yang berbasis inkuiri. Model pembelajaran ini adalah model evidence based learning. Model pembelajaran evidence based learning merupakan model yang menitik beratkan pada usaha menanamkan keterampilan inquiri pada peserta didik dan mengevaluasi dampaknya berdasarkan data yang diperoleh maupun fakta yang teramati selama pembelajaran (Thomson, 2009).

Kemampuan pemahaman konsep dalam pembelajaran fisika merupakan syarat mutlak untuk mencapai keberhasilan belajar. Oleh karena itu, pemahaman konsep memiliki peranan besar untuk mendukung keberhasilan seseorang dalam belajar. Menyadari pentingnya pemahaman konsep dalam pembelajaran fisika, maka perlu memilih model pembelajaran yang tepat dan kemudian direncanakan dengan sedemikian rupa. (Pujianto, 2014).

Pembelajaran yang berbasis bukti menyajikan beberapa teori belajar kognitif yang relevan untuk pemula, ahli dan mendiskusikan implikasinya bagi pembelajaran. Mereka menjelaskan bagaimana strategi pembelajaran berbasis bukti dapat diturunkan dari pembelajaran kognitif teori, dan kemudian menerapkan strategi yang umum untuk digunakan dalam praktik mengajar. Prinsip dasar yang digunakan dalam pembelajaran berbasis bukti praktek adalah bahwa bukti lebih baik dari lainnya yaitu bukti yang diperoleh dari studi yang dirancang dengan baik dan benar untuk memberikan bukti yang lebih baik.

Hasil penelitian yang memberikan dampak lebih baik dalam pembeklajaran diantaranya kajian Ayu (2016) yang mendapatkan bahwa terdapat peningkatan setelah diterapkan model pembelajaran evidence based learning. Selain itu, menurut penelitian yang dilakukan Pujianto (2014) membuktikan bahwa model pembelajaran evidence based learning mampu meningkatkan pemahaman konsep pada peserta didik sehingga hasil belajar meningkat. Hal ini, disebabkan pada model evidence based learning mengandung lima fase kegiatan yang harus dilakukan dalam proses pembelajaran yaitu menentukan pengidentifikasian langkahlangkah dalam proses pembelajaran, mengumpulkan pekerjaan peserta didik, menganalisis hasil pekerjaan peserta didik, memunculkan kondisi yang memungkinkan untuk peserta didik fokus belajar, dan melakukan perubahan-perubahan dalam rangka umpan balik, sehingga mampu memperbaiki pemahaman konsep peserta didik.

Berdasarkan latar belakang yang telah dijelaskan, maka menarik dilakukan penelitian tentang penerapan model pembelajaran evidence based learning untuk meningkatkan pemahaman peserta didik pada materi momentum dn impuls di kelas X Sekolah Menengah Atas.

\section{Metode Penelitian}

Penelitian ini merupakan penelitian kuasi eksperimental dengan rancangan posttest only non-equivalent control group, terhadap peserta didik kelas $X$ di SMA Negeri 9 Pekanbaru Tahun Ajaran 2018/2019, sebagaimana rancangan Tabel 1. Populasi penelitian adalah peserta didik kelas X SMA Negeri 5 Pekanbaru, sedangkan sampel penelitian yaitu peserta didik kelas X IPA $\mathrm{PAn}_{3}$ $\mathrm{X} \mathrm{IPA}_{6}$ yang masing-masing berjumlah 36 orang.

Tabel 1. Rancangan penelitian

\begin{tabular}{lcc}
\hline \multicolumn{1}{c}{ Kelompok } & Perlakuan & Posttest \\
\hline Kelas eksperimen & $\mathrm{X}$ & $\mathrm{O}_{1}$ \\
Kelas kontrol & - & $\mathrm{O}_{2}$ \\
\hline
\end{tabular}

Sumber: (Sugiyono, 2013).

Keterangan :

$\mathrm{X}=$ Perlakuan dengan menerapkan model pembelajaran evidence based learning

$\mathrm{O}_{1}=\quad$ Skor posttest kelas eksperimen 
$\mathrm{O}_{2}=\quad$ Skor posttest kelas kontrol

Teknik pengumpulan data pada penelitian ini melalui teknik tes. Teknik tes digunakan untuk memperoleh data pemahaman konsep peserta didik pada materi momentum dan impuls. Pemberian posttest kepada peserta didik dilakukan setelah proses pembelajaran dengan penerapan model pembelajaran evidence based learning di kelas eksperimen (kelas $\mathrm{X} \mathrm{IPA}_{3}$ ) dan tanpa penerapan model di kelas kontrol (kelas $\mathrm{X} \quad \mathrm{IPA}_{6}$ ). Data yang diperoleh terdiri dari data primer yang langsung diperoleh dari hasil posttest materi momentum dan impuls, sedangkan data sekunder diperoleh dari ulangan harian peserta didik dari materi sebelumnya.

Data dianalisis menggunakan teknik analisis deskriptif dan analisis inferensial. Analisis deskriptif untuk mendeskripsikan atau menggambarkan tentang pemahaman konsep peserta didik. Peningkatan pemahaman peserta didik dapat dilihat melalui skor yang diperoleh peserta didik dari tes hasil belajar yang terdiri dari 10 soal disertai alasan. Adapun penentuan skor pemahaman konsep (SPK) menggunakan persamaan (1) dan kategorinya menurut Tabel 2.

$$
\text { SPK }=\frac{\text { Skor perolehan }}{\text { Skor total }} \times 100 \%
$$

Tabel 2. Kategori pemahaman peserta didik

\begin{tabular}{ccl}
\hline Interval & $\begin{array}{c}\text { Kategori } \\
\text { Daya Serap }\end{array}$ & \multicolumn{1}{c}{$\begin{array}{c}\text { Kategori } \\
\text { Efektivitas }\end{array}$} \\
\hline $85 \leq \mathrm{x} \leq 100$ & Sangat Baik & Sangat Efektif \\
$70 \leq \mathrm{x} \leq 84$ & Baik & Efektif \\
$50 \leq \mathrm{x} \leq 69$ & Cukup Baik & Cukup Efektif \\
$0 \leq \mathrm{x} \leq 49$ & Kurang Baik & Kurang Efektif \\
\hline Sumber: (Depdiknas, 2007) &
\end{tabular}

Analisis inferensial dilakukan melalui uji hipotesis untuk mengetahui perbedaan skor kemampuan memahami konsep peserta didik setelah diterapkan model pembelajaran Evidence Based Learning pada kelas eksperimen dan pembelajaran konvensional pada kelas kontrol. Sebelum melakukan uji hipotesis dilakukan uji prasyarat terlebih dahulu yaitu uji normalitas dan homogenitas. Analisis inferensial dilakukan menggunakan program SPSS versi 23 dengan taraf kepercayaan $95 \%$ yang terdiri dari:

a. Uji normalitas untuk melihat sampel berdistribusi normal atau tidak dan uji homogenitas untuk melihat kedua kelas homogen atau tidak.

b. Uji hipotesis (uji-t) yaitu jika signifikan, $\rho$ $>0,05$, maka Ho diterima (tidak terdapat perbedaan yang signifikan) dan jika signifikan, $\rho<0,05$, maka Ho ditolak (terdapat perbedaan yang signifikan).

\section{Hasil dan Pembahasan}

Data hasil analisis posttesttest peserta didik terhadap pemahaman konsep dengan pembelajaran fisika pada materi momentum dan impuls melalui model pembelajaran evidence based learning di kelas X SMA Negeri 9 Pekanbaru ditunjukkan pada Tabel 3.

Berdasarkan Tabel 3 dapat diketahui rata-rata indikator pemahaman konsep paling tinggi di Kelas Eksperimen dengan persentase $71,73 \%$. Untuk indikator dengan kategori tertinggi adalah translation dan indikator terendah adalah extrapolation pada kelas eksperimen. Selanjutnya pada kelas kontrol, indikator dengan kategori tertinggi adalah translation dan indikator terendah adalah interpretation.

Efektivitas pembelajaran berdasarkan hasil skor pemahaman peserta didik secara keseluruhan pada kelas eksperimen mencapai $71,73 \%$ dengan kategori efektif. Oleh karena itu, efektivitas pembelajaran fisika melalui model pembelajaran Evidence Based Learning (EBL) dinyatakan efektif. pada kelas kontrol hanya mencapai $48,7 \%$ dengan kategori kurang efektif. Oleh karena itu, kategori efektivitas pembelajaran di kelas eksperimen ternyata memenuhi kategori efektif, seangkan si kelas kontrol melalui pembelajaran konvensional diperoleh kurang efektif. Penjelasan setiap indikator diuraikan lebih lanjut. 
142 Jurnal Geliga Sains (JGS): Jurnal Pendidikan Fisika, 7(2): 138-145, 2019

Tabel 3. Skor pemahaman konsep

\begin{tabular}{|c|c|c|c|c|c|c|}
\hline \multirow{3}{*}{$\begin{array}{l}\text { Indikator Pemahaman } \\
\text { Konsep }\end{array}$} & \multicolumn{3}{|c|}{ Kelas Eksperimen } & \multicolumn{3}{|c|}{ Kelas Kontrol } \\
\hline & \multirow{2}{*}{$\begin{array}{c}\text { Skor } \\
\text { Posttest } \\
(\%)\end{array}$} & \multicolumn{2}{|c|}{ Kategori } & \multirow{2}{*}{$\begin{array}{c}\text { Skor } \\
\text { Posttest } \\
(\%)\end{array}$} & \multicolumn{2}{|c|}{ Kategori } \\
\hline & & Daya Serap & Efektivitas & & Daya Serap & Efektivitas \\
\hline Translation & 85,64 & SB & $\mathrm{E}$ & 58,1 & $\mathrm{CB}$ & $\mathrm{CE}$ \\
\hline Interpretation & 68,22 & $\mathrm{CB}$ & $\mathrm{CE}$ & 41,49 & $\mathrm{~KB}$ & $\mathrm{KE}$ \\
\hline Extrapolation & 61,34 & $\mathrm{CB}$ & $\mathrm{CE}$ & 46,52 & $\mathrm{~KB}$ & $\mathrm{KE}$ \\
\hline Rata-rata & 71,73 & B & $\mathrm{E}$ & 48,7 & $\mathrm{~KB}$ & $\mathrm{KE}$ \\
\hline
\end{tabular}

Ket: SB: (sangat baik); B: (baik); CB: (cukup baik); KB: (kurang baik)

E: (efektif); CE: (cukup efektif); KE: (kurang efektif)

\section{1) Translation}

Indikator pemahaman konsep translation merupakan kemampuan peserta didik dalam menerjemahkan hubungan yang digambarkan dalam bentuk simbol, peta, tabel, diagram, grafik, formula, dan persamaan matematis kedalam bahasa verbal atau sebaliknya. Soal-soal indikator translation mengharapkan peserta didik mampu menterjemahkan kejadian berdasarkan gambar, ataupun menterjemahkan suatu prinsip umum melalui ilustrasi (Bloom, 1956).

Pada indikator translation, skor posttest kelas eksperimen lebih tinggi dibanding kelas kontrol. Selisih skor posttest kedua kelas adalah $27,14 \%$. Selisih skor posttest yang cukup besar ini disebabkan oleh penggunaan LKPD pada kelas eksperimen. Penggunaan LKPD 01-A dan LKPD 01-B peserta didik diarahkan untuk menggali pengetahuannya sendiri melalui tampilan video yang telah disediakan oleh guru, sehingga mampu menemukan konsep momentum dan impuls lebih baik. Kemudian peserta didik bersama kelompok dihadapkan dengan masalah dan diminta untuk memecahkan masalah tersebut sesuai dengan fakta yang ditemukan selama proses pembelajaran. Hasil analisis diketahui rata-rata kategori pemahaman translation di kelas eksperimen diperoleh skor 85,64\% dengan kategori pemahaman amat baik. Pada sub indikator translation pertama terdapat 13 orang peserta didik yang mampu menjawab dengan pilihan serta alasan yang tepat. Peserta didik diminta untuk menterjemahkan hubungan yang digambarkan dalam bentuk grafik ke dalam bahasa verbal. Skor tinggi yang didapat, disebabkan telah terlatihnya peserta didik dalam menyelesaikan masalah yang dilakukan sebelumnya melalui LKPD 01$\mathrm{B}$ dalam menemukan konsep impuls.

Berdasarrkan sub indikator kedua, peserta didik diminta untuk menerjemahkan kejadian berdasarkan gambar. Terdapat 15 peserta didik yang mampu menjawab dengan pilihan serta alasan yang tepat. Sedikitnya pencapaian tersebut dikarenakan peserta didik memiliki ketelitian yang minim dalam menggunakan serta merumuskan persamaan matematis tumbukan lenting sebagian sehingga masih banyaknya alasan yang kurang tepat dalam lembar jawaban peserta didik. Selanjutnya pada sub indikator ketiga, peserta didik diminta untuk menerjemahkan suatu prinsip umum melalui ilustrasi. Terdapat 13 peserta didik yang mampu menjawab dengan pilihan serta alasan yang tepat. Hal ini disebabkan masih kurang pahamnya peserta didik dalam memahami konsep impuls dan momentum dalam kehidupan sehari-hari.

\section{2) Interpretation}

Indikator pemahaman konsep interpretation merupakan kemampuan untuk mengenal dan memahami ide utama suatu komunikasi, peserta didik diharapkan mampu menafsirkan berbagai data, memahami peristiwa yang benar berdasarkan gambar dan membedakan pembenaran atau penyangkalan suatu kesimpulan yang terdapat dalam suatu data (Pujianto, 2014). Skor posttest kelas eksperimen pada indikator interpretation lebih tinggi dibanding kelas kontrol. Selisih skor posttest kedua kelas adalah $26,73 \%$. Selisih yang cukup besar ini, disebabkan oleh penggunaan LKPD yang menerapkan model 
pada kelas eksperimen. Pada LKPD 02 peserta didik diarahkan untuk menggali pengetahuannya sendiri melalui tampilan video yang telah disediakan, sehingga menemukan konsep tumbukan. Kemudian peserta didik bersama kelompok dihadapkan dengan pertanyaan untuk melatih kemampuan menafsirkan.

Berdasarkan hasil analisis, rata-rata kategori pemahaman interpretation di kelas eksperimen tergolong cukup baik dengan persentase $68,22 \%$. Setelah ditelaah hanya 1 orang peserta didik yang mampu mencapai kategori pemahaman amat baik. Pada indikator interpretation ini, terdapat 4 sub indikator. Sub indikator pertama, peserta didik diminta untuk memahami suatu ide utama. Terdapat 6 peserta didik yang mampu menjawab soal dengan pilihan dan alasan yang tepat. Sedangkan sisanya dengan pilihan yang tepat, namun alasan kurang tepat. Hal ini disebabkan karena sebagian peserta didik belum mampu memahami dan menyerap secara utuh informasi yang didapat melalui LKPD. Analisis sub indikator kedua, peserta didik diminta mampu menafsirkan berbagai data. Terdapat 28 orang peserta didik yang mampu menjawab soal dengan pilihan dan alasan yang tepat. Artinya pada soal ini, peserta didik mampu menafsirkan sebuah gambar/data.

Sub indikator ketiga menghendaki peserta didik mampu memahami peristiwa yang benar berdasarkan gambar. Terdapat 6 orang yang mampu menjawab soal dengan pilihan dan alasan yang tepat. Sedangkan sisanya dengan pilihan yang tepat namun alasan tidak tepat. Hal ini disebabkan oleh peserta didik yang kurang paham dengan konsep impuls, sehingga alasan yang diberikan masih tidak tepat. Selain itu juga disebabkan oleh tingkat kesulitan soal lebih tinggi dibanding soal interpretation lainnya.

Sub indikator keempat, peserta didik seharusnya mampu membedakan pembenaran kesimpulan yang terdapat dalam suatu data. Tidak terdapat satupun peserta didik yang mampu menjawab dengan pilihan serta alasan yang tepat. Hal ini disebabkan oleh tingkat kesulitan soal yang lebih tinggi dari soal pada indikator interpretation lainnya. Selain itu juga terindikasi bahwa peserta didik belum memahami secara maksimal konsep tumbukan.

\section{3) Extrapolation}

Indikator pemahaman konsep extrapolation merupakan pemahaman konsep yang menuntut kemampuan intelektual lebih tinggi. Indikator ini, peserta didik diharapkan mampu menggambarkan, menaksir atau memprediksi akibat dari tindakan tertentu, meramalkan kecenderungan yang akan terjadi, serta menyisipkan satu data dalam sekumpulan data dilihat dari kecenderungannya (Bloom, 1956). Indikator extrapolation, skor posttest kelas eksperimen lebih tinggi dibanding kelas kontrol. Selisih skor posttest kedua kelas adalah 14,82\%. Berdasarkan hasil analisis, rata-rata kategori pemahaman extrapolation di kelas eksperimen tergolong cukup baik dengan persentase $61,34 \%$ hasil ini sesuai penelitian Ayu (2016) dengan hasil pemahaman konsep yang meningkat. Setelah ditelaah tidak ada satupun peserta didik mampu mencapai kategori pemahaman amat baik. Pada indikator extrapolation ini, terdapat 3 sub indikator. Sub indikator pertama, peserta didik diminta untuk menggambarkan, menaksir atau memprediksi akibat dari tindakan tertentu. Terdapat 23 peserta didik yang mampu menjawab soal dengan pilihan tepat dan alasan kurang tepat. Peserta didik belum memahami optimal konsep vektor, sehingga masih terdapat jawaban yang kurang tepat. Artinya pada soal ini, peserta didik sudah mampu menaksir akibat dari tindakan tertentu, namun belum maksimal.

Sub indikator kedua, peserta didik diminta untuk menyisipkan satu data dalam sekumpulan data dilihat dari kecenderungan nya. Terdapat hanya 6 peserta didik yang mampu menjawab soal dengan pilihan tepat serta alasan tepat. Hal ini disebabkan oleh masih kurangnya pemahaman konsep sebagian peserta didik. Selanjutnya pada sub indikator ketiga, peserta didik diminta untuk manaksir akibat tindakan tertentu. Tidak terdapat satupun peserta didik yang mampu menjawab dengan pilihan serta alasan yang tepat. Hal ini disebabkan oleh tingkat kesulitan soal yang lebih tinggi dibandingkan soal dalam kategori yang sama. Selain itu juga dalam menghitung dan menggunakan persamaan dalam formulasi momentum, serta ketelitian peserta didik yang masih rendah, sehingga peserta didik kesulitan dalam menyelesaikan soal.

Hasil analisis inferensial terhadap uji hipotesis untuk menguji kebenaran 
signifikansinya berdasarkan data yang dari sampel penelitian, diperoleh hasil nilai signifikansi sebesar 0,000 . Jadi $0,000<0,05$ artinya $\rho<0,05$ sehingga Ho ditolak. Dengan demikian terdapat perbedaan yang signifikan pemahaman konsep pada materi momentum dan impuls peserta didik di kelas yang menerapkan model evidence based learning $\left(\begin{array}{lllll}\text { kelas } & \mathrm{X} & \mathrm{IPA}_{3}\end{array}\right)$ dengan kelas dengan pembelajaran konvensional (kelas $\mathrm{X} \quad \mathrm{IPA}_{6}$ ) SMA Negeri 9 Pekanbaru.

Berdasarkan hasil analisis deskriptif dan inferensial, diketahui bahwa secara deskriftif penerapan model evidence based learning dengan kelas X SMA Negeri 9 Pekanbaru efektif dalam memahami konsep momentum dan impuls. Hasil analisis inferensial juga menujukkan adanya perbedaan yang signifikan antara pembelajaran yang menerapkan model evidence based learning terhadap pembelajaran konvensional yang sesuai dengan hasil kajian yang hasilnya meningkat dari (Ayu, 2016). Walaupun hasil penelitian ini mendapatkan hasil sesuai dengan tujuan, namum masih perlu optomalisasi proses pelaksanaan serta disesuaikan dengan materinya, sebab secara deskriptif belum semua peserta didik sampai pada tahap pemahaman konsep yang baik, dimana berdasarkan capaian tahap efektivitasnya baru mencapai tahap efektif.

\section{Kesimpulan dan Saran}

Berdasarkan hasil pembahasan secara deskriptif bahwa pemahaman konsep pada kelas eksperimen yang menerapkan model pembelajaran evidence based learning diperoleh hasil lebih tinggi dibandingkan dengan kelas kontrol, dan melalui uji inferensial menunjukkan terdapat perbedaan pemahaman konsep yang signifikan antara kelas eksperimen dan kelas kontrol. Sehingga dengan model pembelajaran evidence based learning dinyatakan efektif dalam meningkatkan pemahaman konsep peserta didik pada materi momentum dan impuls di kelas $\mathrm{X}_{3}$ SMA 9 Pekanbaru.

Hasil penelitian yang diperoleh baru pada tahap kategori efektif, untuk itu diharapkan dalam menerapkan model pembelajaran Evidence Based Learning lebih dioptimalkan setiap tahapan proses pembelajarannya, agar pemahaman konsep peserta didik libih baik. Selain itu, sebaiknya memanfaatkan teknologi yang sedang berkembang untuk dikolaborasikan dengan model evidence based learning. Model ini juga dapat menjadi salah satu alternatif dalam pelaksanaan pembelajaran inovatif.

\section{Daftar Pustaka}

Ayu, Abriani, 2016. Peningkatan Pemahaman Konsep Mata Pelajaran Fisika dengan Menerapkan Model Pembelajaran Evidence Based Learning dalam Peserta didik Kelas X SMAN 1 Polombangkeng Utara. Makassar. UIN Alauddin Makassar.

Azizah, N., Indrawati, \& Harijanto, A., 2014. Penerapan Inkuiri Terbimbing untuk Meningkatkan Keterampilan Proses Sains dan Hasil Belajar Siswa Kelas X $C$ di MAN 2 Jember Tahun Ajaran 2013/2014. Jurnal Pendidikan Fisika, 3(3): 235-241.

Bloom, Benjamin S., 1956. Taxonomy of Educational Objectives: The Classification of Educational Goals, Handbook I Cognitive Domain. Longmans, Green and Co. New York.

Depdiknas, 2007. Pedoman Penilaian Hasil Belajar. Dirjen Manajemen Dikdasmen, Dirpom TK dan SD, BNSP, Jakarta.

Dwiyanto, 2005. Pembelajaran di Laboratorium. Pusat Pengembangan Pendidikan UGM, Yogyakarta.

Erlina Sofiani, 2011. Pengaruh Model Inquiri Terbimbing (Guided Inquiry) Terhadap Hasil Belajar Fisika peserta didik pada Konsep Listrik Dinamis. Jurnal Pendidikan, 2.

Giancoli, Douglas C., 2001. Fisika. Edisi Kelima Jilid 1. Penerbit Erlangga, Jakarta.

Hasan, Fuad, 2004. Pendidikan adalah Pembudayaaan dalam Pendidikan Manusia Indonesia. Kompas, Jakarta.

Pujianto, 2014. Model Pembelajaran Evidence Based Learning dalam Setting Outdoor Activities sebagai Solusi Alternatif Bentuk Pembelajaran Sains Bagi 
Sekolah di Daerah Rawan Bencana. Jurnal SAINTECH, 02(02).

Sugiyono, 2013. Metode Penelitian Pendidikan (Pendekatan Kuantitatif, Kualitatif, $R \& D)$. Alfabeta, Bandung.
Thomson, J., 2009. Evidence Based Learning for Student and Teachers, The Science Teachers. Journal Proquest.

Young, D. Hugh, \& Roger, A. Friedman, 2002. Fisika Universitas (Terjemahan) Jilid 1. Erlangga, Jakarta. 